\title{
The great US liquidity trap of 2009-2011: are we stuck pushing on strings?
}

\author{
Robert Pollin* \\ Department of Economics and Political Economy Research Institute (PERI), University of Massachusetts \\ Amherst, USA
}

After the onset of the Great Recession in 2008, commercial banks in the United States began accumulating huge cash reserves in their accounts at the Federal Reserve. By the middle of 2011, reserves had reached \$1.6 trillion, more than 10 percent of US GDP, an order of magnitude for commercial bank cash holdings that is without precedent. The key factor allowing banks to accumulate huge cash hoards was that the Federal Reserve had pushed the federal funds rate to near zero by the end of 2008, and held it there through 2011 and beyond. Over this same period, the non-corporate business sector obtained zero net credit. This overall pattern represents the most recent variant of reaching a 'liquidity trap' and trying to 'push on a string.' Under such circumstances, conventional central bank open-market operations are greatly weakened as an expansionary policy tool. This paper examines the experience of the liquidity trap in the United States since the Great Recession began and considers policy approaches for escaping the trap. I provide a critical review of various proposals for escaping liquidity traps, including raising the inflation target, depreciating the currency, and targeting long-term interest rates directly. I also propose two key innovative policies, an excess reserve tax for commercial banks and a major expansion in the federal loan guarantee program for smaller businesses.

Keywords: monetary policy, bank cash hoarding, excess reserve tax

JEL codes: E44, E5, E65

\section{INTRODUCTION}

Since the onset of the Great Recession in 2008, commercial banks in the United States began accumulating huge cash reserves in their accounts at the Federal Reserve. Thus, in 2007, just before the onset of the Wall Street crash and ensuing recession, commercial bank reserves at the Fed totaled $\$ 20.8$ billion. By the end of 2008, that figure had ballooned to $\$ 860$ billion. By the middle of 2011, it had reached $\$ 1.6$ trillion, where it remains as of this writing (June, 2012). This is more than 10 percent of US GDP, an order of magnitude for commercial bank cash holdings that is without precedent since the Federal Reserve began reporting such statistics systematically.

The banks obtained most of these funds through borrowing within the federal funds market - the market for short-term interbank loans - nearly for free, since the Federal

* Address for correspondence: pollin@econs.umass.edu. I am grateful to Long Vuong for research assistance; to James Heintz for working with me to develop many of the ideas and empirical measures presented here; and to an anonymous referee for comments on an earlier draft. 
Reserve pushed their policy target rate, the federal funds rate, close to zero in December 2008. The Fed has held the federal funds rate at close to zero since then, and Fed Chair Ben Bernanke has announced that the Fed plans to keep the federal funds rate at near-zero at least through 2014.

Over this same period that the banks built up these massive cash reserves, credit stopped flowing into the non-corporate business sector in the US. For these smaller businesses, total borrowing fell from $\$ 546$ billion in 2007 to negative $\$ 346$ billion in 2009 - a nearly $\$ 900$ billion reversal. The non-corporate business sector overall continued to obtain zero net credit over both 2010 and 2011. This pattern is especially damaging coming out of the severe employment crisis created by the recession, since, on average, smaller businesses are relatively labor intensive, and thus typically serve as a major engine of job creation during economic recoveries.

These conditions in credit markets over the Great Recession and subsequently are hardly unique relative to previous recessions, in the US and elsewhere, and to the 1930s Depression itself. Indeed, this contemporary experience represents just the most recent variation on the classic problems in recessions in reaching a 'liquidity trap' and trying to 'push on a string.' This is when banks would rather sit on cash hoards than risk making bad loans, and businesses are not willing to accept the risk of new investments, no matter how cheaply they can obtain credit. Under such circumstances, conventional central bank open-market operations - that is, lowering the target shortterm policy - is greatly weakened as a tool for pushing an economy out of a recession and toward a healthy recovery.

The liquidity trap that has prevailed since the 2008-2009 recession has served as a major headwind, counteracting the effects of what, on paper, has been a strongly expansionary macro policy stance by the US government in the face of the Wall Street crash and recession. The expansionary policy measures included the nearly $\$ 800$ billion, 2-year Obama stimulus program, the American Recovery and Reinvestment Act (ARRA). The ARRA was financed by an increase in the federal government's fiscal deficit that was unprecedented over the post-World War II period. The fiscal deficit reached \$1.4 trillion, or 10.1 percent of US GDP in 2009 and \$1.3 trillion, or 9.0 percent of GDP, in 2010. In terms of Federal Reserve Policy, in addition to the near-zero interest rate monetary policy, Chair Bernanke dramatically expanded the Fed's lending facilities during the recession to include mortgage brokers, money market funds, and insurance companies. The Fed also purchased commercial paper directly immediately after the recession. Finally, the Fed engaged in two rounds of quantitative easing, beginning in November 2008 and November 2010 respectively, which involved the Fed purchasing long-term Treasury bonds in an effort to directly bring down long-term lending rates. Despite all of these measures, the recovery out of recession has been weak and fitful. The threat of a double-dip recession is ongoing as of this writing.

The focus of this paper is to examine the experience of the liquidity trap in the United States since the recession and to consider policy approaches for escaping the trap. While it is of course true that pushing on a string accomplishes nothing, pulling on a string is a different matter altogether. The question then becomes: are there interventions that the Federal Reserve and other policymaking bodies can pursue that will enable the policies to pull on a string? Attempting to answer this question is the most basic aim of this paper. Though the paper does not consider fiscal policy interventions in general or the ARRA in particular in depth, the underlying premise of the discussion here is that any measures specifically designed to escape the liquidity trap will need to be combined with further expansionary fiscal 
policies to strengthen aggregate demand in order to produce a strong and sustainable recovery. ${ }^{1}$

This paper is structured as follows. In section 2, I review data on the nature of the contemporary US liquidity trap. We know the commercial banks have been carrying unprecedented amounts of cash reserves. But how do we know whether these reserves are excessive, given the high levels of ongoing risk in the economy? I conclude here that at least $\$ 1$ trillion of the $\$ 1.6$ trillion in reserves can be defined as excessive. This extremely high level of excess reserves stands in sharp contrast to the collapse of credit extended to smaller businesses since the recession began, which I also review in this section.

Section 3 explores the causes of the liquidity trap. I argue that there are two basic causes: the lack of aggregate demand in the economy and the high rate at which banks have rejected loan applications by small businesses. In combination, these demand and credit-market constraints have established an overarching high level of risk - that is, a broadly-based risk constraint inhibiting a recovery. By referring to a risk constraint as the basis for the liquidity trap, my purpose is to emphasize that, for the most part, it is not that firms see no market opportunities at all - which would make them demandconstrained only - or that they are unable to obtain a loan at any interest rate, making them purely credit-constrained. It is more likely that firms have been unable to obtain a loan on terms that were favorable enough for them to realize profit opportunities through investments, given existing market conditions.

In section 4, I evaluate a range of policy approaches that have been proposed for dealing with liquidity traps in general, and the current US circumstances in particular. These proposals were mostly introduced in the literature in response to the Japanese deflation and liquidity trap of the 1990s. The two most prominent are to raise the economy's inflation rate target or to depreciate the currency. I argue that these are not likely to be effective in the current US circumstances. Another set of proposals is for the Federal Reserve to intervene to directly reduce long-term interest rates that, as we will see, have not fallen commensurately with the decline in the federal funds rate. This approach is more promising in my view, insofar as it is aimed directly at lowering long-term rates on business loans, as opposed to long-term Treasury rates. However, I argue in this section that the two most promising interventions would be: (1) instituting an excess reserve tax, or its equivalent, to create a direct disincentive for banks to hoard cash; and (2) expanding the federal government's loan-guarantee program to smaller businesses, thus directly counteracting the economy's aggregate-level risk constraint. These measures are targeted precisely to influence important features of the liquidity trap, while they could also be undertaken readily and at low cost using existing federal government policy tools.

The paper concludes in section 5 with a brief review of the main findings and policy suggestions. The overarching policy finding is that, in order for the US economy to move onto a sustainable growth trajectory, the federal government needs to combine another round of expansionary fiscal policies at roughly the level of the 2009-2011 ARRA with equally expansionary credit market policies - that is, a set of measures explicitly aimed at escaping the liquidity trap, as opposed to having the Fed simply provide the commercial banks with unlimited cash reserves through its near-zero interest rate policy.

1. Pollin (2010 and 2012) deals in depth with issues tied to fiscal policy and the ARRA. 


\section{EXCESS BANK RESERVES AND THE COLLAPSE OF SMALL BUSINESS LENDING}

Figure 1 shows the level of cash reserves held by US commercial banks and other depository institutions - including savings banks, savings \& loans, cooperative banks and credit unions - between 2001 and 2011 (the most recent data available). ${ }^{2}$ As the figure shows, between 2001 and 2007, commercial banks held between $\$ 17.5$ and $\$ 20.8$ billion in total cash reserves. The banks then increased their cash reserves from $\$ 20.8$ to $\$ 860$ billion between 2007 and 2008, an $\$ 840$ billion increase. By the end of 2011, bank reserves had increased still further to an astronomical $\$ 1.6$ trillion, which is more than 10 percent of US annual GDP for 2011.

Of course, banks need to maintain a reasonable supply of cash reserves as a safety margin against future economic downturns. One of the main causes of the 2008-2009 crisis and other recent financial crises was that banks' cash reserves were far too low. But at what point does prudence become excessive, as a symptom of a liquidity trap? This is the question we examine here.

\subsection{Why are banks holding so much cash?}

The main reason the banks have built up this unprecedented cash hoard is that, since the recession began, the Federal Reserve has pursued an aggressive accommodative monetary policy, in an effort to counteract the recession and promote a strong recovery. The main tool deployed by the Fed in this regard has been to hold the federal funds rate at near zero percent since December 2008. Figure 2 shows the movement of the federal funds rate since 2006, before the recession began. As we see, the Fed aggressively pushed this interest rate down, beginning in mid-2007 as the financial market crisis began to spread. After peaking at 5.26 percent in July 2007, the Fed pushed this rate down to 0.15 percent as of January 2009. Since then, through December 2011, the federal funds rate ranged between 0.07 and 0.22 percent. $^{3}$

In short, the commercial banks have built up this unprecedented cash hoard primarily because they have been able to obtain these funds virtually for free. Furthermore, since October 2008, for the first time in its history, the Federal Reserve has paid the commercial banks an interest rate of 0.25 percent for holding these reserves within the Fed's coffers (Keister and McAndrews 2009). This means that the banks are earning profits through a pattern whereby they borrow at a zero percent rate on the federal funds market, then collect a 0.25 guaranteed return by depositing these funds with the Federal Reserve. The banks also have the option of borrowing at the Federal Funds rate, then purchasing virtually risk-free US Treasury debt at rates between 2 and 3 percent, depending on the maturity of the bonds.

\subsection{How much cash should banks hold to be safe?}

What would have been an appropriate level of cash reserve holdings for commercial banks and other depository institutions over 2008-2011, after taking realistic account

2. As a shorthand hereafter, we will use the terms 'commercial banks' or just 'banks' to refer to the full set of US depository institutions.

3. Moreover, as recently as April 2012, the Fed reaffirmed its commitment to maintain its near-zero federal funds rate policy through 2014. 


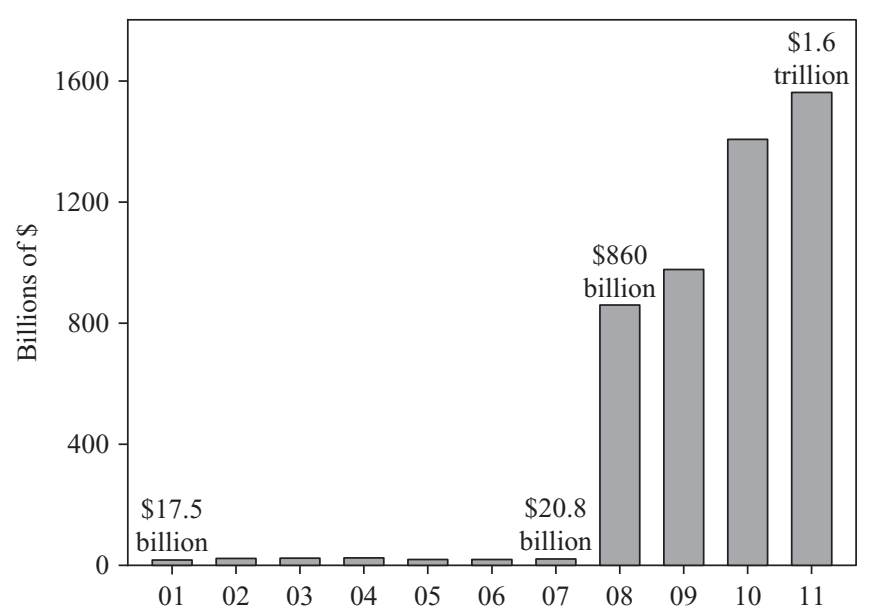

Source: Flow of Funds Accounts of US Federal Reserve System.

Figure 1 Cash reserve holdings by US commercial banks, 2001-2011

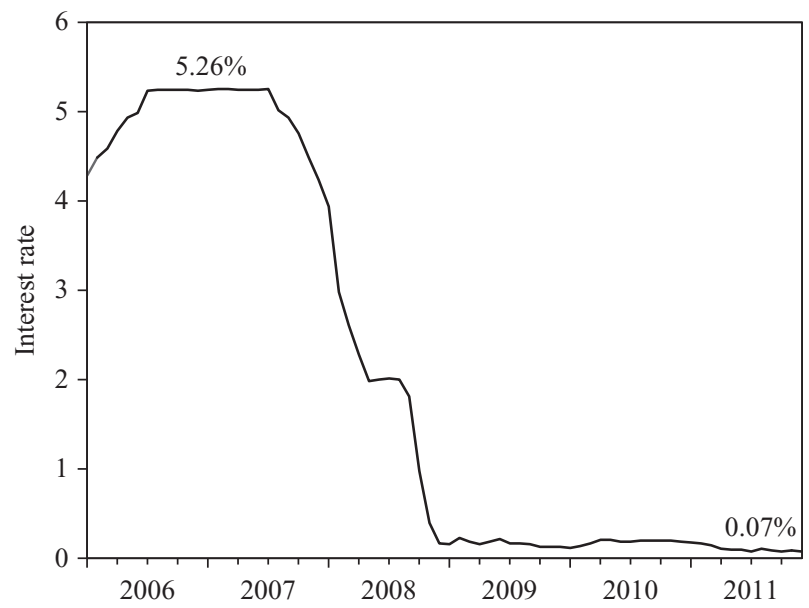

Source: Economagic website.

Figure 2 US federal funds rate, 2006.01-2011.12

of the weak recovery and high level of ongoing risks in the economy, including the threat of a double-dip recession?

One way to pursue that question is to examine the level of cash reserves that these institutions have held at similar points during previous economic recovery periods, while still making some significant allowances for the severity of the most recent recession and the weakness of the subsequent recovery. Following that theme, I present in Table 1 the figures for cash reserves held by US commercial banks and 
Table 1 US commercial bank cash reserves relative to bank liabilities and GDP during six economic recovery periods

\begin{tabular}{lccc}
\hline & $\begin{array}{c}\text { Commercial bank } \\
\text { reserves (billions \$) }\end{array}$ & $\begin{array}{c}\text { Reserves as pct of } \\
\text { bank liabilities }\end{array}$ & $\begin{array}{c}\text { Reserves as } \\
\text { pct of GDP }\end{array}$ \\
\hline $\begin{array}{l}1973 \\
\text { following 11/70 recession trough }\end{array}$ & 27.1 & $3.6 \%$ & $1.9 \%$ \\
$\begin{array}{l}1977 \\
\text { following 3/75 recession trough }\end{array}$ & 26.9 & $2.9 \%$ & $1.3 \%$ \\
$\begin{array}{l}1985 \\
\text { following 11/82 recession trough }\end{array}$ & 28.6 & $1.4 \%$ & $0.7 \%$ \\
$\begin{array}{l}1993 \\
\text { following 3/91 recession trough }\end{array}$ & 35.0 & $1.2 \%$ & $0.5 \%$ \\
$\begin{array}{l}\text { fo04 } \\
\text { following 11/01 recession trough }\end{array}$ & 24.0 & $0.4 \%$ & $0.2 \%$ \\
$\begin{array}{l}\text { 2011 } \\
\text { following 6/09 recession trough }\end{array}$ & 1595.9 & $15.3 \%$ & $10.5 \%$ \\
\hline
\end{tabular}

Note: Figures are for two years into economic recoveries.

Source: Flow of Funds Accounts of Federal Reserve System.

other depository institutions approximately two years after the onset of an economic recovery out of a recession. I then measure that level of cash reserve in proportion to the banks' total liabilities as well as overall US GDP in each of the time periods.

As we see in the second column of the table, cash reserves (shown in current dollar figures) have ranged fairly narrowly in absolute terms from 1973 to 2004 two years into recoveries, at between $\$ 24$ and $\$ 35$ billion. However, considered as a share of both bank liabilities as well as US GDP, bank cash reserves were at their peak during the recovery of 1973, at 3.6 percent of liabilities and 1.9 percent of GDP. This ratio then falls in each subsequent recovery period prior to the current one. By 2004, bank reserves were only 0.4 percent of liabilities and 0.2 percent of GDP. We then see the spike in the ratios for 2011: cash reserves were 15.3 percent of liabilities and 10.5 percent of US GDP.

Given the severity of the financial crisis of 2008-2009, it would be reasonable to allow that banks would hold cash reserves well in excess of any previous economic recovery period as a share of both their total liabilities as well as US GDP. Thus, as a rough rule of thumb, we may want to allow that the ratio of cash reserves relative to bank liabilities or GDP should be approximately double the ratio reached during the 1973 peak, at approximately 7 percent of bank reserves or 4 percent of GDP. This would imply a level of cash reserves at between $\$ 600$ and $\$ 700$ billion. ${ }^{4}$ This is in contrast with the actual current level of $\$ 1.6$ trillion. Making this adjustment would mean the amount of excess cash reserves is between $\$ 900$ billion and $\$ 1$ trillion.

\subsection{Allowances for an unstable mortgage market}

In addition to making allowances for commercial banks' cash reserves strictly on the basis of broad historical patterns, one could also approach the issue based on more

4. Total bank liabilities for 2011 were $\$ 10.3$ trillion and US GDP was $\$ 15.1$ trillion. 
specific metrics - that is, with respect to the vulnerabilities that banks have faced concerning home mortgages coming out of the recession. A review of some basic evidence here can provide useful perspective.

The Federal Deposit Insurance Corporation (FDIC) provides data on mortgages held by all US depository institutions, including savings and loans and credit unions in addition to commercial banks. The total is about $\$ 2.5$ trillion in total outstanding mortgages for 1-4 family residential properties. Of the total stock of outstanding residential mortgages, about 70 percent are direct mortgages to purchase homes secured by the value of the property. Another 25 percent of current mortgages are home equity loans. The remaining 5 percent are mortgages secured by junior liens only (that is, liens that have a lower priority in terms of their legal claim on a property). ${ }^{5}$

What has been the level of default risk associated with these loans over the recession and recovery through 2011? According to the most recent figures from the New York Federal Reserve, the mortgage delinquency rate nationwide was 5.3 percent in 2010.3. ${ }^{6}$ This is the fraction of mortgages whose payments are 90 days or more past due. If we assume that all these delinquent mortgages will lead to a default an implausibly high proportion of defaults relative to delinquent loans - this represents a potential loss of the banks and other depository institutions of $\$ 132.5$ billion in asset values. ${ }^{7}$ Assume also that all of the defaulted mortgages are held by commercial banks, as opposed to the other depository institutions. If we finally assume that the banks should hold cash reserves to cover double the amount of the potentially defaulted loans, that would suggest a total additional level of cash holdings of $\$ 265$ billion. This figure is still less than half the low-end figure of $\$ 600$ billion I reach by calibrating a safety margin relative to total bank liabilities or US GDP.

Another way of assessing the banks' needs for cash reserves specifically in terms of default risk for outstanding mortgages in this regard is to consider the costs to depository institutions of having to write off residential mortgages. In the aftermath of the financial crisis, residential write-offs for all depository institutions rose from $\$ 8.0$ billion in 2007 to $\$ 27.2$ billion in 2008 , and peaked at $\$ 55.3$ billion in 2009 . The figure then fell to $\$ 50.1$ billion for $2010 .^{8}$ If we assume that the commercial banks should carry cash reserves to cover write offs at the peak 2009 level of $\$ 55$ billion for 5 years, that would imply a total need for cash reserves for this purpose of $\$ 275$ billion. Once again, this figure is less than half the $\$ 600$ billion that we are proposing the banks retain as a cash reserve to cover heavy risks.

To summarize, according to both the approaches I consider to derive a very highend estimate of needs for cash reserves by commercial banks based on conditions in the home mortgage market through 2011, my conclusion is that this figure could reach

5. FDIC Statistics on Banking, www2.fdic.gov/SDI/SOB/. Note that the total outstanding mortgage debt within the US economy as of 2011.2 is $\$ 10.4$ trillion. This means that commercial banks hold approximately 24 percent of total outstanding mortgage debt. The remaining 76 percent of total mortgage debt is held by non-bank financial institutions. However, for estimating the needs of commercial banks themselves for a cash reserve safety cushion given current conditions in the mortgage market, the relevant reference point is the banks' own holdings of $\$ 2.5$ trillion in outstanding mortgages, not the economy-wide total of $\$ 10.4$ trillion.

6. New York Federal Reserve Bank, US Credit Conditions, Mortgages, http://data.newyorkfed. org/creditconditionsmap/.

7. Based on 2011 data from the Standard and Poor's consumer default index, the proportion of delinquent loans that ended in default was 60 percent.

8. Figures on write-offs for residential mortgages come from the Federal Deposit Insurance Corporation. 
close to $\$ 300$ billion. Thus, for the banks to carry instead $\$ 600$ billion in reserves - the figure I reached by scaling the need for reserves relative to historical patterns of reserves/GDP during previous business cycle recoveries - would entail holding roughly twice as much as would be needed to heavily fortify themselves in managing their fragile balance sheets based on the patterns for mortgage delinquencies and foreclosures. If the banks did indeed carry $\$ 600$ billion as a safety reserve, this would still imply that, through 2011 , they were holding about $\$ 1$ trillion in excess reserves. ${ }^{9}$

\subsection{Lending and borrowing for businesses}

While the US commercial banks and other depository institutions carried an unprecedented supply of cash reserves out of the recession through 2011, the level of borrowing and lending within the business sector fell dramatically over this same period. For non-corporate businesses, including most smaller firms, the level of borrowing and lending was still not close to achieving a recovery as of the end of 2011.

We can observe these patterns in Figure 3. As the figure shows, for non-financial corporations, borrowing fell from $\$ 871$ to $\$ 4.3$ billion between 2007-2009 (in real 2011 dollars). Corporate borrowing did then recover strongly in 2010-2011. However, the pattern is much more severe for non-corporate businesses. For these firms, borrowing fell from $\$ 526$ billion in 2007 to negative $\$ 346$ billion in 2009. That is, in 2009, non-corporate businesses did no net borrowing, but rather paid back $\$ 346$ billion in outstanding loans. Put another way, over 2009, smaller businesses made repayments at a level of more than 2 percent of total US GDP rather than borrowing to inject new spending into the economy. Non-corporate businesses in the aggregate then continued this basic pattern through 2011, with non-corporate firms still undertaking virtually no net borrowing three years after the Wall Street crash.

\section{CAUSES OF THE LIQUIDITY TRAP}

Since the Japanese deflationary experience in the 1990s, there has been a growing literature seeking to explain the causes of liquidity traps as well as policies to escape them. Blinder (2000) provides a good overview on the state of mainstream research at that time, as follows:

Fundamentally, the issue is this: Does an economy with a zero nominal interest rate follow more or less the same economic laws as it does in normal times - except that one variable is stuck at zero? Or is the situation more akin to physics at zero gravity, or near absolute zero

9. Of course, I have derived this estimate for the US commercial banks' adequate level of liquidity much less formally that would be established by following the Basle III liquidity coverage requirements, the implementation for which began in June 2012 (Bank for International Settlements 2010). Nevertheless, it is clear that the $\$ 600$ billion figure I have derived informally for the banks' safety reserve at the end of 2011 is far in excess of what would be derived following Basle III. Under Basle III, the 'liquidity coverage ratio' is defined as: [(Stock of high-quality liquid assets)/(total net cash outflows over the next 30 calendar days) $\geq 100$ percent]. The term 'high-quality liquid assets' is of course subject to variation over the course of a business cycle; but certainly cash reserves held at the Federal Reserve - and to be specific $\$ 600$ billion worth of such cash reserves - will always qualify as such. 


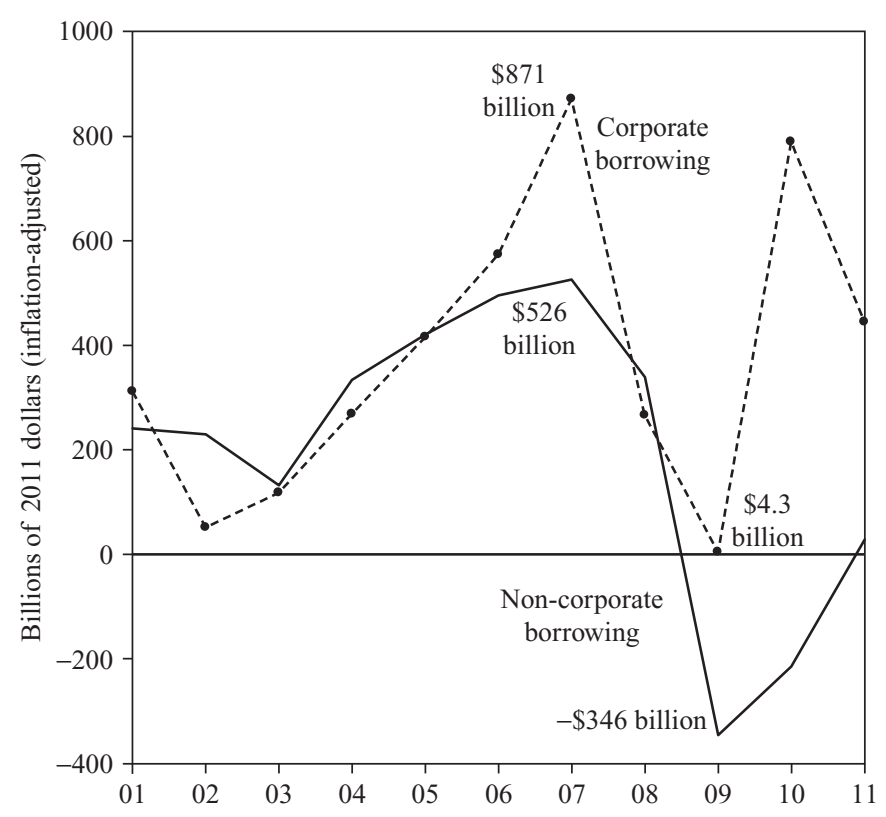

Note: Inflation adjustment with PPI.

Source: Flow of Funds Accounts of Federal Reserve System.

Figure 3 US nonfinancial corporate and non-corporate business borrowing, 2001-2011

temperature, where behavior is fundamentally different, even strange? I think the conclusion we seem to be reaching ... is that it may indeed be a new world... (p. 1093 $)^{10}$

As is suggested in Blinder's comment, most of the mainstream literature focuses on conditions at the zero interest-rate bound itself, as opposed to addressing the broader set of conditions pushing the economy to become stuck at the zero rate bound. Michl (2010) presented an alternative approach, which precisely attempts to frame the specific phenomenon of a prevailing zero interest rate with the broader conditions that pushed the financial markets into the liquidity trap. Building from Hyman Minsky's model of investment, Michl argues that three factors will be crucial in pushing an economy toward a liquidity trap: (1) low underlying ex-post profitability of capital; (2) weak expectations about future profitability; and (3) uncertainty about prospective yields. But Michl's discussion of these factors with respect to most recent experience focuses on the longer-term patterns leading up to the financial crisis as opposed to the experience during the crisis itself.

My discussion here focuses instead on the experience since the 2008 financial crisis and subsequent recession. With respect to this period, the three factors cited by Michl weak realized profits, expectations of weak profit prospects into the near future, and a

10. Blinder's paper is especially useful because it summarizes the main findings of a range of contributors from a conference at the Boston Federal Reserve on exactly the subject of policy options within a liquidity trap. 
high level of uncertainty surrounding any profit calculations - have all been present, pushing the economy into its liquidity trap. We can see this by considering more precisely the proximate factors behind the low realized profits and profitability expectations as well as the high levels of investor uncertainty.

The first proximate factor is the ongoing weakness of aggregate demand, creating a demand constraint on recovery. This is the case because low realized profitability in the present and expected profitability into the future can be the result of firms facing either (1) high total costs of production; or (2) weak market demand for their products. Since labor costs - the most important business cost in the aggregate - did not rise after the recession, it therefore means that profitability was primarily constrained by weak market demand. The second proximate factor is the badly malfunctioning credit market itself, creating a credit constraint on recovery. As we will see, the badly functioning financial market acts as an independent factor, compounding the problem of weak market demand. In addition, as I discuss below, the demand and credit market constraints on growth interact with one another, to create an overarching risk constraint on recovery.

\subsection{Demand constraints}

Businesses - both financial and non-financial entities - operate to earn a profit. If banks are choosing to hoard cash rather than channel funds for productive investments, at some level this must be because they do not see adequate profit opportunities by moving the funds into productive investments. More precisely, following Michl, they are looking at the combination of realized profits since the recession hit, the weak prospects for healthy profit opportunities into the recovery, and the level of uncertainty around any such profit opportunities; and are calculating that holding cash hoards is a better use of their funds. The single most important reason why they do not see adequate profit opportunities for new investments is that there are insufficient levels of market demand in the economy. The low level of demand is a direct consequence of three factors: (1) the combination of high unemployment and high inequality; (2) the collapse of household wealth tied to the bursting of the financial bubble in 2008; and (3) the austerity policies being imposed by state and municipal governments. We consider these factors in turn.

\subsubsection{Unemployment and inequality}

As is well known in any Keynesian model, high unemployment feeds on itself in a vicious cycle. In addition to direct, measurable multiplier effects that make markets less buoyant, high unemployment also creates a broadly-shared sense of anxiety about the future, even among those who are employed. This further dampens household spending and weakens market demand. All of these factors have been at play over 2009-2011, when official unemployment averaged more than 9 percent, the highest 3-year average since the 1930s Depression.

Corresponding to the high unemployment well into the recovery, the long-standing pattern of rising inequality also sharply reasserted itself during the recovery, after having been briefly reversed due to the fall in financial assets tied to the financial collapse. Thus, by the end of World War II, in 1946, the highest income families - the top 1 percent - obtained 13 percent of all income and the top 10 percent obtained 37 percent. By the mid-1970s, the share of the top 10 percent had fallen to 33 percent of total 
income. However, beginning in the early 1980s, with the election of Ronald Reagan as President, this trend toward increasing income equality reversed itself. By 2007, just as the economic crisis was emerging, the top 1 percent's share of total income had risen to 24 percent $-2 \frac{1}{2}$ times its share in 1970 . The top 10 percent received 50 percent of all income, 17 percentage points more than in $1970 .{ }^{11}$ According to the most recent calculations by Saez, for 2010, the first full year after the recovery began officially in July 2009, 93 percent of the total income growth was received by the richest one percent of the population (Saez 2012).

The rising level of inequality further contributed to weakening market demand, because of differences in the consumption functions of wealthy and non-wealthy households, with the non-wealthy devoting virtually all the income they receive on purchasing goods and services, while the wealthy use a disproportionate share of their high incomes for speculating on financial markets. Correspondingly, if the trend toward rising inequality is reversed, this in turn will help strengthen overall market demand. It will also contribute toward reducing speculative forces in financial markets. ${ }^{12}$

\subsubsection{Collapse of household wealth}

Figure 4 shows the movements of real household wealth in the US between 2001 and 2011. As the figure makes clear, household wealth rose sharply between 2002 and 2006 , from $\$ 51.0$ to $\$ 70.7$ trillion, in step with the inflating financial bubble. But household wealth then collapsed along with the bubble - falling by $\$ 17.6$ trillion between 2006 and 2008 to $\$ 53.1$ trillion, a nearly 25 percent decline in just two years. Even with household wealth having recovered by the end of 2011, the figure was still at $\$ 58.4$ trillion, 17.4 percent below the 2006 peak. Research examining the wealth effect on consumption (for example, Maki and Columbo 2001) generally finds a wealth effect of between 3 and 5 percent in total spending relative to the change in household wealth - that is, over the recession, that households would have reduced their spending by between 3 and 5 cents for every dollar of wealth that they lose. This does assume, as is likely under the recent circumstances, that the households see this loss of wealth as a long-term change in their financial situation. Thus, even taking the lower-end 3 percent estimate as the size of the wealth effect, the loss of \$17.6 trillion in household wealth would imply a roughly $\$ 525$ billion reduction in household spending.

A crucial component in this overall pattern of household wealth decline was the fall in housing market values. The decline in household real estate values between 2006 and 2008 was $\$ 6.8$ trillion - that is, nearly 40 percent of the overall $\$ 17.6$ billion fall in overall household wealth. But the fall in home values was by far the most significant effect for the overwhelming majority of non-wealthy households in the US, since these households have never held significant portfolios of assets other than their own homes. The collapse in home values in turn pushed 23 percent of US

11. The patterns on inequality are surveyed well in MacEwan and Miller (2011).

12. The most recent extensive research on this issue is Onaran and Galanis (2012). They consider the effects of changes in the wage share of national income for the United States as well as multiple countries in the Euro area. Their policy conclusion is that the US economy, as well as the global economy, are wage led, and that a recovery would therefore be strengthened through an increase in the wage share of national income. These findings are also consistent with related earlier studies, including Stockhammer and Stehrer (2009). 


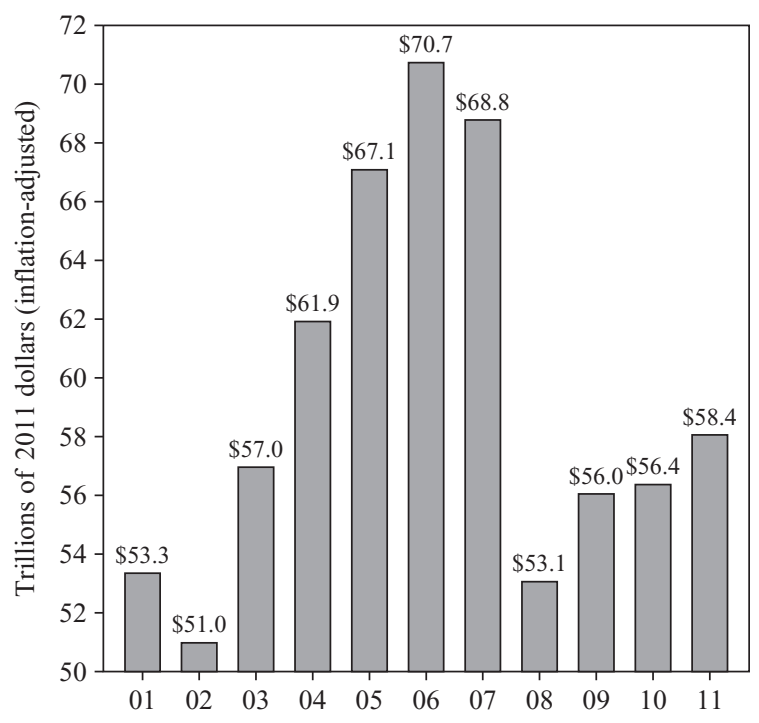

Note: Inflation adjustment with CPI-U.

Source: Balance Sheets of US Economy.

\section{Figure 4 US household net worth, 2001-2011}

homeowners 'underwater' - that is, the market value of their homes has fallen below the outstanding mortgage debt on the home. Having one's home fall underwater creates further financial difficulties. A homeowner is no longer able to borrow against the value of his/her home. It also becomes much more difficult to sell one's home and relocate, and therefore to find employment by moving to another community. These factors in turn contribute to the overall weakening of market demand. ${ }^{13}$

\subsubsection{Austerity policies}

The recession led to severe fiscal crises for state and municipal governments throughout the US. Tax receipts - particularly income and sales taxes - dropped severely along with household incomes, spending, and real estate values. Meanwhile demand for public services, such as Medicaid and heating oil assistance, rose automatically as the recession created worsening circumstances for tens of millions of people. The net result of the collapse of tax revenues and the rising demand for state services has been budgetary shortfalls of $\$ 191$ billion in 2010, $\$ 130$ billion in 2011, and a projected $\$ 112$ billion in 2012. The 2011 shortfall is equal to 19 percent of all state spending commitments (see Pollin and Thompson 2011).

Revenue-sharing support from the federal government did help cover about onethird of these revenue shortfalls in 2009-2010, as part of the ARRA stimulus program. But federal stimulus funds ran out after two years. A smaller portion of the overall spending gap was covered in ten states by raising taxes, in some cases in a progressive

13. The problem of underwater mortgages is surveyed well in the 2011 study by New Bottom Line. 
way. But the biggest adjustment was through state and local governments enacting budgetary cuts. These spending cuts have major impacts on living standards for non-wealthy people throughout the country, since state and local governments are the most important providers in the US of education, health care, public safety, and other vital forms of social support. In addition, collectively, state and local governments are the largest employer in the country, responsible for creating 30 million jobs, either directly or through purchasing supplies or services from private businesses. ${ }^{14}$ This is roughly 20 percent of the US workforce. Thus, cuts to state and local governments will lead to significant declines in employment, which, again, produces declining household spending. The cuts also mean weakening markets for those private businesses who sell supplies to state and local governments.

\subsection{Credit market constraints}

We reviewed above economy-wide aggregated data on the absence of credit flowing to small businesses since the recession began. We can also observe this same pattern at the level of individual firms. Indeed, considering individual firm-level data, there is strong evidence of a high proportion of small businesses being willing to borrow to expand their operations, even under weak recovery conditions, but being denied credit outright or seeing the costs of borrowing as too high relative to the levels of market risk. Thus, a summer 2011 survey by Pepperdine University's Graziadio School of Business and Management found that 95 percent of business owners report wanting to execute a growth strategy, but only 53 percent were obtaining the funding they needed to execute that strategy. Meanwhile, bankers were reporting that they were rejecting 60 percent of their loan applications (Paglia 2011). These results are similar to those from a survey conducted by the New York Federal Reserve Bank in October 2010, about 10 months earlier. The Fed survey reported that roughly three-quarters of those who applied for credit were either turned down outright or had only part of their request met, with fully one-third receiving no funds. The two sectors facing the most difficulties in obtaining credit were construction and retail. The Fed survey did also find that these credit market obstacles were operating in tandem with declining sales as major factors facing small businesses in the aftermath of the financial crisis and recession. $^{15}$

In addition to businesses getting their loan applications turned down outright, borrowing rates for average businesses remained relatively high during the recession and through 2011, even while commercial banks have been able to borrow on the federal funds market at near-zero rates since the beginning of 2009. We can see this in Figure 5, which shows the monthly movements of the federal funds rate and the Baa corporate borrowing rate from 2001.01 to 2011.12. The Baa rate applies to corporations that are perceived as sufficiently low-risk to obtain an investment-grade bond rating, while still being at the high-risk end of investment-grade firms. The rates that would apply to non-corporate businesses would generally be higher than the Baa rate, as they would be perceived as more risky than an average corporation. As Figure 5 shows, the Baa rate did fall in correspondence with the Federal Reserve

14. These figures are estimated by using the US Department of Commerce Input-Output model of the US economy, as developed through IMPLAN.

15. 'Access to Credit: Poll Evidence from Small Businesses,' Facts \& Trends, Federal Reserve Bank of New York, October 2010, http://www.newyorkfed.org/regional/2010_Facts_Trends_ Vol_3_2.pdf. 


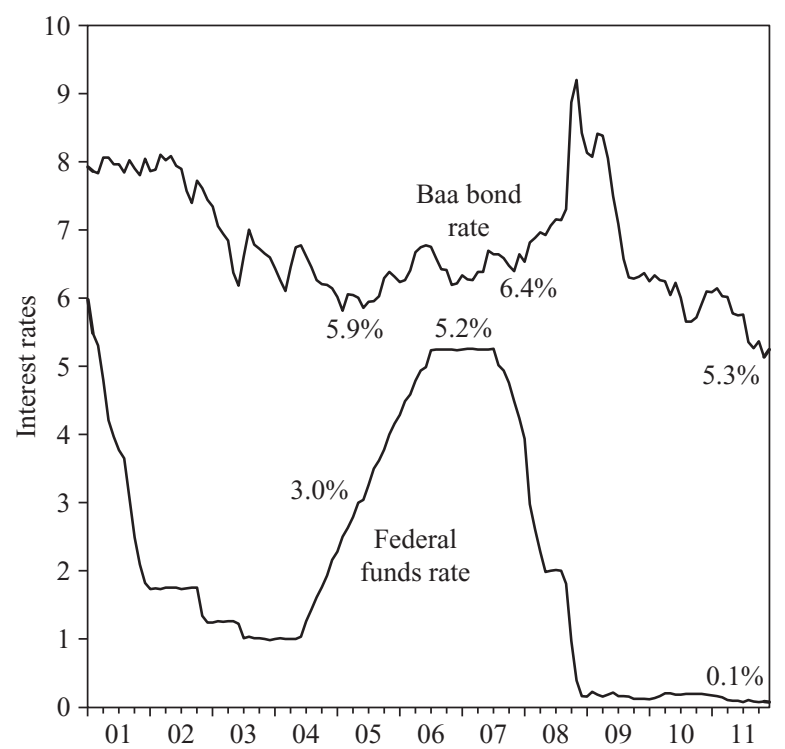

Note: Baa bonds and federal fund rates, monthly figures 2001.01-2011.12.

Source: Economagic website.

\section{Figure 5 Interest rates for business borrowers vs commercial banks}

maintaining the federal funds rate at close to zero since 2009.1. However, the decline of the Baa rate is relatively modest, especially given the Fed's extremely accommodating policy stance. That is, the Baa rate as of 2011.12 was 5.27 percent, only modestly lower than the Baa rate of 5.86 percent that prevailed in mid-2005 when the federal funds rate was 3.04. Even when the Fed set the federal funds rate as high as 5.25, the Baa rate averaged about 6.4 percent.

\subsection{Risk constraints: demand plus credit constraints}

In fact, a high percentage of businesses, most especially smaller businesses, are likely to be both demand- and credit-constrained, to varying degrees within sectors and between individual firms. That is why a more generally applicable way of assessing conditions from the financial crisis through 2011 is to recognize that businesses have been 'risk-constrained.' That is, it is not that most firms see no market opportunities at all - which would make them demand-constrained only - or that they are unable to obtain a loan at any rate, making them purely credit-constrained. It is more likely that firms were unable to obtain a loan on terms that were favorable enough for them to realize profit opportunities through investments, given existing market conditions. From this perspective, the collapse of net borrowing and lending, especially with respect to smaller non-corporate businesses, reflects a high level of risk aversion by both borrowers and lenders with respect to new productive investments. The case is similar with respect to large corporations, which were flush with cash by the end of 2011, but were using the funds for financial engineering rather than 
productive investments and job creation. The reason they are committed to financial engineering as opposed to expanding their productive activities is not that they see no market opportunities at all. Rather, they anticipate better returns and lower risks through buybacks as opposed to expanding their operations. ${ }^{16}$

\section{STRATEGIES FOR ESCAPE}

Are there ways to effectively extricate an economy mired in a liquidity trap? This section considers five approaches, including (1) raising the inflation rate; (2) depreciating the currency; (3) targeting policies to directly influence long-term interest rates; (4) instituting an excess reserve tax or its equivalent; and (5) expanding the federal government's loan-guarantee program to smaller businesses.

\subsection{Raising the inflation rate}

The most prominently discussed idea for escaping the liquidity trap is for the Federal Reserve to raise its inflation target, from its current level at 2 percent to perhaps 4 percent (the level proposed, for example, by Blanchard et al. 2010). Assuming the Fed could then achieve and sustain the higher-targeted inflation rate for the appropriate time period, its impact would of course be to lower the purchasing power of money, including, in particular, all cash hoards. This would create an incentive for those hoarding cash to move their depreciating funds into some kind of investment that yields a return above the targeted inflation rate.

Svennson (2003) characterizes this idea of generating a higher inflation rate over a fixed period of time as his 'foolproof' approach to escaping the liquidity trap. But in fact, this approach is by no means foolproof. Rather, it would be extremely difficult for even the most capable central bankers to execute successfully. The most important reason is that, especially in a liquidity trap, the Federal Reserve does not have any direct policy tool for moving the actual inflation rate up or down as it pleases. After all, the primary tool available to the Fed for influencing the inflation rate is open-market operations targeted at the federal funds rate. But the whole problem of falling into a liquidity trap is that making changes in the federal funds rate - including pushing the federal funds rate to near-zero, which we know the Fed can accomplish - will not automatically stimulate economic activity. How then can we assume that the Fed can simply switch on a higher inflation rate through relying on this tool in a liquidity trap? Moreover, none of the other tools in the Fed's arsenal - including all variants of bailout operations - would be any more effective than conventional open-market operations at controlling the inflation rate in a liquidity trap. A basically similar situation holds as well for fiscal policy. That is, as we have seen over the period in which the ARRA operated, the federal government cannot move the economy at will to a

16. Pollin et al. (2011) examine the major build up of liquid asset holdings by US nonfinancial corporations, reaching over $\$ 2$ trillion by the end of 2011 . This phenomenon emerged in correspondence with the rise of the commercial banks' build-up of cash reserve holdings. But as we show in the 2011 study, the pattern for the nonfinancial corporations is not nearly as significant a deviation from previous balance sheet structures as in the case of the commercial banks. 
desired higher level of activity, or a desired higher inflation rate, simply by having undertaken a given stimulus program. ${ }^{17}$

It is true that, all else being equal, achieving a higher inflation rate would generate additional effects that could alter the liquidity trap dynamics, as Krugman (2000; 2012) has emphasized. One important effect is that it lowers the real value of outstanding dollar-denominated debts, benefiting debtors at the expense of creditors. The point here would be to encourage aggregate spending by shifting aggregate net worth from more-wealthy creditors to less-wealthy debtors. Another effect of a higher inflation rate is that it lowers the real value of nominal wage contracts, which would transfer real income from employees to business owners. The point here would be to encourage businesses to hire more workers, given that real wages will be lower. But in considering these two factors, note that any decline in real wages induced by rising inflation would have the opposite impact in terms of income and wealth transfers as the shift in net worth between debtors and creditors. These two effects would thus work to neutralize one another as means of escaping the liquidity trap.

\subsection{Depreciation of the exchange rate}

In most cases, a dollar depreciation would emerge as one outcome within an overall package of effects resulting from raising the economy's inflation rate. But the Federal Reserve could also attempt to depreciate the exchange rate even while undertaking no efforts to change the inflation rate. Still, in either case, as both Svensson (2003) and Blinder (2000) recognize to some extent, this approach is also unlikely to be successful as a solution to a liquidity trap, especially in considering the contemporary US conditions. The most basic issue is similar to that with the inflation target. That is: does the US have the capacity to lower the value of the dollar relative to other currencies as it chooses in the current period? As long as the severe instability in the Eurozone continues unresolved, as is the case midway through 2012, this remains a highly unlikely proposition. It is also more generally the case that lowering the value of the dollar has much broader implications beyond its impact on the US liquidity trap alone. It would strengthen the US competitive position and correspondingly weaken that of US trading partners. The governments whose businesses depend heavily on selling products in the US market would obviously protest against a dollar depreciation and could retaliate. Further, would we want to escape the liquidity trap by beggaring the economies of our trading partners, even if it were technically possible to do so? Similar problems would emerge with respect to foreigners holding US dollar denominated assets. As of 2012 , foreigners were holding $\$ 5.1$ trillion in Treasury debt alone. These foreign dollar asset holders would almost certainly take action against measures to depreciate the dollar, which would, in turn, diminish the impact of any such measures.

17. In addition, a major factor moving the inflation rate is supply shocks, oil price movements in particular. Fluctuations in oil prices, in turn, are heavily influenced by speculative financial activities in the commodities futures market (see, for example, Pollin and Heintz 2011). The federal government could exert more influence over oil prices in particular, and the overall inflation rate in general, through maintaining strong regulations on commodities futures market speculation. Such measures were incorporated into the Dodd-Frank financial regulatory system that became law in 2010. But it remains an open question as to whether such measures will be enforced effectively (Epstein and Pollin 2011). The current high level of uncertainty over the enforcement of Dodd-Frank is only one measure of the difficulties policymakers face in trying to maintain control over the inflation rate. 


\subsection{Directly dropping long-term interest rates}

The idea here is that the Fed would target long-term rates, which are still well above having hit the zero bound. For example, as we have seen, the Baa corporate rate has declined only modestly in response to the federal funds rate having been pushed to near-zero. Blinder (2000) considers two variations on this approach in his survey of policy alternatives. The first is for the Federal Reserve to purchase long-term Treasuries, and the other is for the Fed to conduct open-market operations with private assets.

Variations on both ideas have already been implemented in the US and Europe under the term 'quantitative easing' (QE). In the US case, the first period of Fed QE interventions after the 2008 financial crisis was from November 2008 to June 2010, during which time the Fed purchased mortgage-backed securities as well as longer-term Treasuries. The Fed's second QE intervention was between November 2010 and June 2011, during which time it focused on purchasing long-term Treasuries. The two QE interventions did contribute to keeping US Treasury rates low, even while the US Treasury was running historically large fiscal deficits. For example, 10-year Treasuries ranged between 1.9 and 3.8 percent between 2009 and 2011. This in turn has been crucial in allowing the US Treasury to borrow heavily over this period while still maintaining historically low levels of interest payments (Pollin 2012 documents federal interest payments over this period). The Fed's purchases of mortgage-backed securities also helped prevent that market from collapsing during the 2008-2009 crisis.

At the same time, these QE interventions by the Fed did not succeed in significantly bringing down long-term rates for business borrowers. Rather, the QE policies contributed toward widening the interest rate spread between Treasury bonds that are free of default risk and commercial bonds, which carry default risk. This pattern is not surprising. The problem that has characterized the US liquidity-trap period since the 2008 crisis is precisely the high level of default risk and widely-held perceptions that these will be ongoing. This necessarily drives up the spreads between bonds that carry default risk versus those that do not. The QE interventions were not designed to directly address this rising spread between government and commercial paper, but rather primarily to bring down the spreads between short- and long-term government paper. Thus, because of its modest impact on interest rates facing business borrowers, the $\mathrm{QE}$ interventions were not well-targeted at escaping the liquidity trap.

Blinder's other suggestion - for the Fed to push down business borrowing rates directly through open market operations on private assets - addresses more directly the liquidity trap problem. But this approach would also face major difficulties. The first is that the Fed would have to develop protocols for purchasing private assets that do not appear to favor any given set of business interests over others. The lack of such clear protocols was one of the major problems with the Treasury's 20082009 bailout operations, in which the Fed and US Treasury allowed Lehman Brothers to fail while AIG, Goldman Sachs, JP Morgan and others received government support. New political minefields will certainly open up to the extent that the Fed engages in open market operations on commercial paper on a regular basis.

This problem becomes still more serious in recognition of the second issue Blinder raises, which is that any such interventions would have to operate on a very large scale to be effective in moving the interest rates that apply to business borrowers. Thus, at the end of 2011, outstanding bonds in the US markets for both financial and non-financial corporations stood at $\$ 9.7$ trillion. Moving the effective yields on these and newly-issued bonds would entail a level of intervention comparable to that which 
the Fed now conducts with its short-term Treasury purchases and sales. In 2011, the Fed was a net purchaser of $\$ 642$ billion in Treasuries.

Overall then, in principle, this type of intervention could be made workable as a means of countering the US liquidity trap. But it would entail a major new redefinition and scaling-up of Federal Reserve operations for it to be successful. As such, it would be difficult to successfully undertake this type of intervention on its own, especially within the relatively short time-period that would be needed to help the US economy emerge out of the contemporary liquidity trap. Other tools are therefore necessary.

\subsection{Taxing excess bank reserves and guaranteeing small business loans}

I introduce these two proposals together for three reasons. The first is that they are most precisely targeted at addressing the specific symptoms of the contemporary liquidity trap - that is, the huge cash hoards being carried by commercial banks and the high levels of ongoing risks faced by both the banks and non-financial businesses, as reflected in the depressed levels of lending/borrowing for smaller businesses. Second, these two policies could be implemented with relative ease and low cost, relying on the federal government's existing policy tool kit. Finally, they would work most effectively as complements to one another since, between them, they combine one carrot and one stick.

\subsubsection{Excess reserve tax}

The stick would be for the federal government to tax the excess reserves now held by banks. This should create a strong disincentive for banks to continue holding massive cash hoards. The logic behind this approach was described well by Edlin and Jaffe in 2009:

Could we stimulate the economy by setting a maximum on excess reserves ... or a tax on reserves ... ? A tax on excess reserves is a policy equivalent to paying a negative interest rate on reserves, and would account for the perceived social value of lending out reserves in excess of private value. Suppose a policy of negative interest rates on reserves were used to drive down excess reserves by a few hundred billion dollars ... Banks would then need to loan more money out or return deposits and force depositors to find other places to lend their money or invest it. Sure, some loans would go bad. But even bad loans are as likely to stimulate the economy as the stimulus package. (pp. 3-4)

It is difficult to know in advance what the appropriate tax rate should be for this purpose - probably in the range of 1-2 percent. But any such initiative should also allow government to operate with flexibility, to adjust the rate as needed for channeling excess reserves into job-generating investments. This type of flexibility could probably be most effectively implemented by the Federal Reserve acting on its own, by setting a maximum reserve level that would be comparable to the existing minimum reserve requirements the banks now face (as proposed by Dasgupta (2009)). If a bank exceeded the maximum reserve level, they would then have to pay a fee to the Fed.

The Fed could take the first small step along these lines by ending their current policy of paying banks 0.25 percent interest on their reserve holdings, which only encourages hoarding. The reason given by the Fed for paying interest to banks to hoard cash is that it discourages banks from lending too much money quickly to 
consumers and businesses. This, according to the Fed's reasoning, could encourage inflation, once the consumers and businesses start spending their new supply of borrowed funds. But it is clear that, faced with a liquidity trap, the overriding problem facing the Federal Reserve is not excessive inflation, but, precisely, how to extricate the economy from the liquidity trap.

\subsubsection{Expanding business loan guarantees}

The carrot would be to substantially reduce the level of risk being faced by both borrowers and lenders by expanding the federal government's existing loan guarantee programs. The logic behind such an initiative, especially in combination with the excess reserve tax, was also expressed well by Edlin and Jaffe in 2009:

In their more candid moments, bankers are saying they would be delighted to lend more if only they could find more creditworthy borrowers. Of course, there is likely a distinction in this downturn between the private incentives to lend and the social benefits, which would include getting the economy moving again. After all, the reason many business projects are not creditworthy is because the project's prospective customers are cutting back since they too can't get credit. Recessions involve a coordination failure which tends to make the social return to loans higher than the private return. (p. 3)

Edlin and Jaffe themselves proceed from this observation to advocating an excess reserve tax alone. But clearly their point also suggests the need for the government to support guarantees for business loans, because the social returns to lending will be higher than the risk-adjusted private returns. A government loan guarantee is precisely a mechanism for bringing the social and private risk-adjusted returns to lending/ borrowing into alignment.

In terms of practical implementation of such a program, the federal government does already operate various loan guarantee programs on a massive scale. Thus, for 2012, the total level of loans guaranteed by the federal government was about $\$ 780$ billion. This equals about 2.8 percent of all outstanding debt held by US households and domestic non-financial businesses. By far the largest category of loan guarantees was housing subsidies, at $\$ 528$ billion, including $\$ 278$ billion for guarantees of mortgage-backed securities and $\$ 230$ billion for Federal Housing Authority mortgage insurance programs. About $\$ 127$ billion were for non-housing business loans, with $\$ 95$ billion for small businesses through the Small Business Administration and another $\$ 32$ billion through the Export-Import bank. ${ }^{18}$ Under conditions as of mid-2012, the federal government should pursue an agenda to roughly triple as rapidly as possible its overall loan guarantee program to non-housing-related businesses to about $\$ 450$ billion in total, with the focus on the expansion on small businesses. That would entail an increase of guaranteed loans for small business of about $\$ 300$ billion. This would represent a major expansion of the existing federal guarantee programs, while still remaining within the scale of existing overall programs. For this initiative to be effective at significantly reducing risk and encouraging new business investment, the terms on the guaranteed loans would have to be generous - that is, with very large guarantees, in the range of 90 percent; low or no fees on the loans; and low interest rates for borrowers.

18. The data on federal loan guarantees as of 2012 come from the United States Office of Management and Budget (2012). The data on total outstanding debt is from the US Flow-ofFunds Accounts of 3/12, Table L.1. 
As mentioned above, one crucial feature of this combination of policies is that its impact on the federal budget would be negligible. Loan guarantees are contingent liabilities for the federal government. This means that, beyond some relatively modest increase in administrative costs, the government would incur costs from the loan guarantee program only as a result of defaults on the guaranteed loans. Even if we assumed, implausibly, that the default rate on the new loans was twice the proportion that prevailed in 2007, prior to the recession, this would still increase the federal budget by only 0.6 percent. ${ }^{19}$ Moreover, a significant share of this budgetary expense could be covered by the revenues generated by the excess reserve tax. Overall then, this combination of policies provides a low-cost route for pushing the economy out of its liquidity trap.

\subsection{Learning to pull on strings}

The 2008-2009 financial crisis and Great Recession have created the conditions which pushed the US economy into a severe liquidity trap. Under the Federal Reserve's monetary policy through 2011, commercial banks have been free to borrow unlimited amounts of reserves at near-zero interest rates. The banks have taken full use of this opportunity, accumulating $\$ 1.6$ trillion in cash reserves, more than 10 percent of US GDP.

To be sure, commercial banks need to hold a share of these funds as a safety reserve. But by my calculations, the level of reserves that the banks need to maintain an excessively large safety margin, circa 2011-2012, would be around $\$ 600$ billion. This still leaves at least $\$ 1$ trillion that the banks should be moving into lending to support productive investments. Yet, in the aggregate, lending to smaller businesses to finance productive projects stopped altogether from 2009-2011. This lack of business borrowing has been the result of the heavy risk constraints that have emerged in the wake of the recession. The heavy risk constraint includes weak levels of aggregate demand combined with the banks rejecting applications for credit by smaller businesses at a high rate. The fact that the interest rates that would apply to smaller businesses fell only modestly between 2009-2011, even as the federal funds rate was pushed to near-zero, also discouraged businesses from taking on debt and expanding their operations while aggregate demand remained weak.

Under this combination of circumstances, the Fed's near-zero interest rate has indeed amounted to pushing on a string. But that does not mean that there are no policy tools available through which the central bank can gain leverage within the currentday liquidity trap - that is, to develop the capacity to pull on the string. Among the range of policy proposals that have been made in the contemporary literature, I have argued that the two most widely discussed - that is, raising the inflation rate and depreciating the dollar - are not likely to provide policymakers with significant new leverage within the liquidity trap.

19. If we assume $\$ 300$ billion in new loan guarantees which carry a 90 percent guarantee, then allow for a default rate of 3.5 percent, twice the rate in 2007, the net government liability is $\$ 9.5$ billion (that is, $\$ 300$ billion $\times 0.9 \times 0.35$ ). One could of course adjust the calculations based on an increase in either the default rate or the extent of the guarantee. The overall impact on the federal budget would not change significantly within any reasonable range for these variables. See Pollin (2009) for a fuller discussion on how to set the parameters and estimate the costs of government loan guarantee programs. 
However, three other proposals are more likely to achieve significant new policy leverage. First, the Fed could undertake open-market operations on private assets, with the aim of directly bringing down long-term rates for business borrowers. The failure of quantitative easing interventions was not that they were targeted at longterm rates in general, but that they were directly influencing long-term Treasury rates only. This intervention meant that the interest rate spread between long-term Treasuries and private bonds grew, since the quantitative easing policies did nothing to reduce the risk premium embedded in long-term private rates.

But, even more promising, the Fed could impose maximum reserve requirements, which would be the equivalent of an excess reserve tax. Along with this stick of a policy, the federal government should then provide a carrot of substantially expanding the federal loan guarantees for smaller businesses. Through this combination of measures, the government would be aiming policy interventions with precision at two central problems associated with the liquidity trap. That is, banks would become forced to pay a price for hoarding excess cash reserves, while both the banks and non-financial businesses would see the high risks of borrowing/lending fall sharply. Moreover, as I have discussed, these policies can be implemented on a large scale with only modest impact on the federal budget.

Such policies for escaping the liquidity trap will have to be combined with a new round of fiscal stimulus policies to directly bolster aggregate demand. The dismal performance of the US economy since the fiscal crisis began in 2008 has made clear that only through combining an expansionary fiscal stance with equally expansionary credit market policies that is, policies capable of pulling on a string - will the US economy have a fighting chance of achieving a strong and sustainable recovery out of the Great Recession.

\section{REFERENCES}

Bank for International Settlements (2010), 'Basel III: International Framework for Liquidity Risk Measurement, Standards, and Monitoring,' Basel Committee on Bank Supervision, Basel: BIS, December.

Blanchard, Olivier, Giovanni Dell'Ariccia, and Paolo Mauro (2010), 'Rethinking Macroeconomic Policy,' IMF Staff Position Notes, International Monetary Fund, February 12, http://www.imf.org/external/pubs/ft/spn/2010/spn1003.pdf.

Blinder, Alan (2000), 'Monetary Policy at the Zero Lower Bound: Balancing the Risks,' Journal of Money, Credit, and Banking, 32(4): 1093-1099.

Dasgupta, Swapan (2009), 'Comment on Luigi Zingales: Why Not Consider Maximum Reserve Ratios?' The Economists' Voice, 6(4): March.

Edlin, Aaron S. and Dwight M. Jaffe (2009), 'Show Me the Money,' The Economists' Voice, 6(4): March.

Epstein, Gerald and Robert Pollin (2011), 'Regulating Wall Street: Exploring the Political Economy of the Possible,' in Philip Arestis (ed.), Microeconomics, Macroeconomics and Economic Policy: Essays in Honor of Malcolm Sawyer, London: Palgrave Macmillan, pp. 268-285.

Keister, Todd and James McAndrews (2009), 'Why are Banks Holding So Many Excess Reserves?' Federal Reserve Bank of New York Staff Report \#380, July, http://www.newyorkfed.org/ research/staff_reports/sr380.pdf.

Krugman, Paul (2000), 'Thinking About the Liquidity Trap,' Journal of the Japanese and International Economies, 14, 221-237.

Krugman, Paul (2012), End This Depression Now! New York: W.W. Norton and Company.

MacEwan, Arthur and John Miller (2011), Economic Collapse, Economic Change: Getting to the Roots of the Crisis, Armonk, NY: M.E. Sharpe Publishers. 
Maki, Dean M. and Michael G. Columbo (2001), 'Disentangling the Wealth Effect: A Cohort Analysis of Household Saving in the 1990s,' Washington, DC: Board of Governors of Federal Reserve System, http://www.federalreserve.gov/pubs/feds/2001/200121/200121pap.pdf.

Michl, Thomas (2010), 'Falling into the Liquidity Trap: Notes on the Global Economic Crisis,' Amherst, MA: Political Economy Research Institute Working Paper Series, \#215, http:// www.peri.umass.edu/fileadmin/pdf/working_papers/working_papers_201-250/WP215.pdf.

New Bottom Line (2011), 'The Win-Win Solution: How Fixing the Housing Crisis Will Create 1 Million Jobs,' August, <docs.google.com/viewer?a=v\&pid=explorer\&chrome=true\&srcid= 0B9c6kkQ4vZbeMzc3N2NmMGEtOThlZS00NTQzLWJhNDktMGZiN2EwYzRiZTU1\&hl= en_US>.

Onaran, Ozlem and Giorgos Galanis (2012), 'Is Aggregate Demand Wage-Led or Profit-Led? National and Global Effects,' Conditions of Work and Employment Series No. 31, Geneva: International Labour Office.

Paglia, John K. (2011), 'State of Small Business Report,' Pepperdine Private Capital Markets Project, Fall. www.bschool.pepperdine.edu/privatecapital.

Pollin, Robert (2009), 'Interest Rate Exogeneity: Theory, Evidence, and Policy Issues for the U.S. Economy,' Economiaz, 72(3): 244-268.

Pollin, Robert (2010), 'Austerity is Not a Solution,' Challenge, 53(6): 6-36.

Pollin, Robert (2012), 'U.S. Government Deficits and Debt Amid the Great Recession: What the Evidence Shows,' Cambridge Journal of Economics, 36(1): 161-188.

Pollin, Robert and James Heintz (2011), 'How Wall Street Speculation is Driving Up Gasoline Prices Today,' Amherst, MA: Political Economy Research Institute Research Brief, June, http://www.peri.umass.edu/fileadmin/pdf/research_brief/PERI_AFR_Research_Brief_ June20.pdf.

Pollin, Robert, James Heintz, Heidi Garrett-Peltier, and Jeannette Wicks-Lim (2011), 19 Million Jobs for U.S. Workers: The Impact of Channeling \$1.4 Trillion in Excess Liquid Asset Holdings into Productive Investments, Amherst, MA: Political Economy Research Institute, http://www.peri.umass.edu/fileadmin/pdf/published_study/PERI_19Million.pdf.

Pollin, Robert and Jeffrey Thompson (2011), 'State and Municipal Alternatives to Austerity,' New Labor Forum, 20(3): 22-30.

Saez, Emmanuel (2012), 'Striking it Richer: The Evolution of Top Incomes in the United States,' manuscript, Department of Economics, University of California-Berkeley, http://elsa.berkeley. edu/ saez/saez-UStopincomes-2010.pdf.

Stockhammer, Engelbert and Robert Stehrer (2009), 'Goodwin or Kalecki in Demand? Functional Income Distribution and Aggregate Demand in the Short Run,' PERI Working Paper Series, \#203, http://www.peri.umass.edu/fileadmin/pdf/working_papers/working_papers_201-250/ WP203.pdf.

Svennson, Lars E.O. (2003), 'Escaping from a Liquidity Trap and Deflation: The Foolproof Way and Others,' Journal of Economic Perspectives, 17(4): 145-166.

United States Office of Management and Budget (2012), Federal Credit Supplement, Budget of the U.S. Government, Fiscal Year 2013, Washington, DC, http://www.whitehouse.gov/sites/ default/files/omb/budget/fy2013/assets/cr_supp.pdf. 